\title{
ANALISIS RISIKO PRODUKSI USAHATANI PADI LADANG DI DESA NGGELA KECAMATAN WOLOJITA KABUPATEN ENDE
}

\author{
Willybrordus Lanamana \\ Dosen Program StudiAgroteknologi Fakultas Pertanian Universitas Flores \\ J1. Sam Ratulangi-Paupire, Ende-Flores, NTT \\ wlanamana@yahoo.com
}

\begin{abstract}
This study aims to analyze the risk of field rice farming in the dry season and rainy season and the influence of the use of production inputs on the risk of field rice production. The research was conducted in Nggela village with consideration. a) is a dryland village with the main food commodities of paddy rice Field rice farmers in Nggela village as many as 53 farmers, all farmers were studied to get the data and information needed. Analysis of the data used is the coefficient of variation. This analysis is a measure of relative risk obtained by dividing the standard deviation with the expected value. . The magnitude of the influence of input use on production risk was analyzed using multiple linear regression, the production function used was the Cobb Douglass production function beginning with the classical assumption test. The results of the analysis show that the risk of producing paddy rice farming in the rainy season is lower than in the dry season. The results of the t-test analysis show that not all independent variables have a significant effect on the dependent variable. Variables that are not influential are labor variables. Data in the field shows that the workmanship in Nggela village is still familiar with the pattern of cooperation, so that a lot or a little workforce is used that does not affect the risk of production. In the variables of land, seeds, fertilizers, and pesticides, there is a significant and negative sign, this means that any additional land area, seeds, fertilizers and pesticides will reduce the risk of field rice production.
\end{abstract}

Keywords: Production risk, rice field

\section{PENDAHULUAN}

Desa Nggela merupakan salah satu desa lahan kering di Kabupaten Ende dengan karakteristik, lahan kering yang relatif luas, hari hujan dan bulan hujan rendah serta topografis wilayah yang berbukit, fakta demikian berpengaruh pada kehidupansosial ekonomi pertanian masyarakat desa Nggeladalammemanfaatkan sumber daya lahan kering untukmenjaga kelangsungan hidupnya. Salah satu komoditas pangan utama masyarakat desa Nggela adalah padi ladang, komoditas ini dibudidayakan secara turun temurun, transformasi pengetahuan dan teknologi terjadi juga secara turun temurun. Budidaya padi ladang memiliki keterkaitan dengan budaya lokal, sehingga dari pengolahan lahan sampai dengan panen tidak dapat dipisahkan dari ritual perladangan, ritual ini menjadi penanda bahwa usahatani padi ladang merupakan suatu kebudayaan bagi masyarakat setempat. 
Budidaya padi ladang di desa Nggela tidak berarti tanpa permasalahan, salah satu diantaranya adalah produktivitasnya yang masih rendah.Produktivitas padi ladang di Desa Nggela tahun 2017 baru mencapai 20,00 kw/hektar sedangkan rata-rata produksi padi ladang di Propinsi NTB sudah mencapai 40,65 kw/hektar, produktivitas rata-rata padi ladang nasional 33,62 kw/ hektar (Lanamana, 2016). Suryana et al (2009) menguraikan beberapa problematik yang berkaitan dengan usahatani padi di Indonesia antara lain a). kepemilikan lahan usahatani yang kecil dan menyebar b). keterbatasan debit air terutama pada musim kemarau c). keterbatasan tenaga kerja d) keterbatasan modal dan e) serangan hama penyakit.

Petani di Desa Nggela memiliki pengalaman panjang dalam usahatani padi ladang, pengetahuan dan keterampilan diwariskan secara turun temurun, namun pengalaman initidak serta merta memberi pengaruh terhadap produktivitas dan pendapatan usahatani. Hasil wawancara dengan beberapa petani memberi gambaran bahwa, walaupun petani menggunakan lahan dengan karakteristik yang sama, pengetahuan dan teknolologi yang sama namun perbedaan produktivitasantara individu petani cukup signifikan, fenomena ini terjadi bertahun-tahun. Secara teoritis perbedaan ini sangat ditentukan oleh penggunaan faktor-faktor input pertanian.

Petani di desa Nggela sebagian besar merupakan petani subsisten, hal ini terlihat dari kepemilikan lahan sempit dan menyebar, teknologi rendah, modal terbatas, produksi untuk memenuhi kebutuhan hidupnya sendiri, jika kelebihan produksi baru dibarterkan dengan hasil pertanian lainnya atau dijual. Dalam menjalankan kegiatan usahatani padi ladang, petani tidak pernah melakukan perhitungan biaya dan pendapatan/ analisa usahatani, secara faktual yang ditemukan, petani hanya berusaha untuk menghindari kegagalan agar usahatani padi ladang dapat terus dijalankan, sehingga kebutuhan pangan rumah tangga dapat terjaga, usaha tani padi ladang bukan untuk mencari keuntungan. Permasalahanpermasalahan di atas merupakan resiko yang harus dihadapi petani di desa Nggela. Terminologi resiko diartikan sebagai kemungkinan terjadinya suatu kejadian yang tidak menguntungkan bagi petani, semakin tinggi ketidakpastian pada suatu keadaan, maka semakin tinggi resiko yang dihadapi (Soedjana, 2007). Menurut Semaoen (2000), resiko baik keluaran maupun peluang dapat diketahui, sedangkan menurut Roumaset (2000), resiko merupakan salah satu ukuran dari dispersi hasil-hasil yang mungkin, probabilitas yang menghasilkan keputusan tertentu dan yang harus dibayar oleh mereka yang tidak mampu menghindar. Petani diharapkan mampu mengidentifikasi resiko dan meminimalisir resiko dengan mengendalikan berbagai permasalahanpermasalahan di atas. Penelitian ini bertujuan untuk menganalisis resiko usahatani padi ladang pada musim 
kemarau dan musim hujan serta pengaruh penggunaan input produksi terhadap resiko produksi padi ladang di desa Nggela.

\section{METODE PENELITIAN}

Penelitian ini dilaksanakan di desa Nggela kecamatan Wolojita kabupaten Ende, pemilihan lokus penelitian didasarkan pada beberapa pertimbangan, a) Nggela merupakan desa lahan kering dengan komoditas pangan utama padi ladang b) petani padi padang di desa Nggela merupakan petani subsisten c) karakteristik petani yang subsisten dengan pendapatan yang rendah sangat rentan terhadap resiko produksi d) penelitian tentang resiko usahatani belum pernah dilakukan di desa Nggela. Penelitian dilakukan pada bulan Februari - April 2016. Petani padi ladang di desa Nggela sebanyak 53 Orang petani, jumlah ini relatif terus berkurang setiap tahun. Tenaga kerja usia produktif kurang tertarik bekerja disektor pertanian, sehingga 53 orang petani tersebut merupakan tenaga kerja usia non produktif. Petani berjumlah 53 orang ini diteliti untuk mendapat data dan informasi yang dibutuhkan..

Untuk mengetahui besarnya resiko produksi dianalisis menggunakan koefisien variasi (CV), secara matematis dirumuskan sebagai berikut: $\mathrm{CV}=\frac{\sigma}{\gamma}$ Koefisien variasi merupakan ukuran resiko relatif yang diperoleh dengan membagi standar deviasi dengan nilai yang diharapkan. Nilai koefisien variasi yang lebih kecil menunjukkanvariabilitas nilai rata-rata pada distribusi tersebut rendah.Hal ini menggambarkan risiko yang dihadapi untukmemperoleh produksi tersebut rendah. Menurut Kadarsan (1995), untuk menganalisis resiko usaha dapat dilakukan dengan menggunakan langkah-langkah perhitungan hasil yang diharapkan (E). Dalam mengukur resiko secara sistematik, maka digunakan ukuran ragam (varian) dan simpangan baku (standar deviasi). Hal ini menunjukkan semakin besar nilai koefisien resiko, maka semakin besar yang akan ditanggung petani padi ladang.

Analisis ini antara lain pernah digunakan oleh Ihsanudin (2010) yaitu tentang resiko usahatani tembakau di Kabupaten Magelang, Lamusa (2010) menganalisis resiko usahatani padi sawah rumah tangga di daerah Impenso Provinsi Sulawesi Tengah, dan Arifin (2013) menganalisis resiko produksi dan pendapatan kepemilikan lahan daerah sentra produksi padi di Kabupaten Pinrang. Besarnyapengaruh penggunaan input terhadap risiko produksidianalisis dengan menggunakan regresi linier berganda, diawali dengan uji asumsi klasik. Modelregresi untuk pengaruh penggunaan input terhadapproduksi dan terhadap risiko produksi secara umumdituliskan sebagai berikut:

$\operatorname{Ln} Y=a+a_{1} \ln x_{1}+a_{2} \ln x_{2}+a_{3}$ $\ln \mathrm{x}_{3}+\mathrm{a}_{1} \ln \mathrm{x}_{4}+\mathrm{a}_{1} \ln \mathrm{x}_{4}+\mathrm{a}_{5} \ln \mathrm{x}_{5}+\mathrm{a}_{\mathrm{mt}}$ $\mathrm{D}_{\mathrm{mt}}+\mathrm{e}^{2}=\mathrm{a}+\mathrm{a}_{1} \ln \mathrm{x}_{1}+\mathrm{a}_{2} \ln \mathrm{x}_{2}+\mathrm{a}_{3} \ln$ $\mathrm{x}_{3}+\mathrm{a}_{1} \ln \mathrm{x}_{4}+\mathrm{a}_{1} \ln \mathrm{x}_{4}+\mathrm{a}_{5} \ln \mathrm{x}_{5}+\mathrm{a}_{\mathrm{mt}}$ $\mathrm{D}_{\mathrm{mt}}+\mathrm{e}$

\section{Keterangan:}

$\mathrm{Y}=$ produksi padi ladang $(\mathrm{kg})$

$\mathrm{I}^{2}=$ resiko produksi padi ladang

$\mathrm{a}=$ intersept 


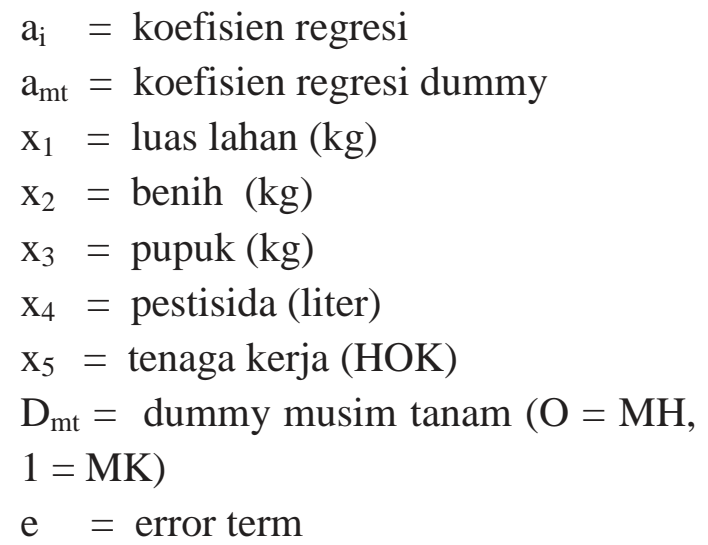

\section{HASIL DAN PEMBAHASAN}

Penggunaan Input Pertanian

Petani di desa Nggela menggunakan benih untuk kegiatan budidaya diambil dari padi yang disimpan dari tahun sebelumnya, ratarata setiap rumah tangga petani menyimpan padi untuk masa paceklik atau untuk ditanam pada tahun berikutnya dalam jumlah yang cukup banyak, kebiasaan ini sudah berlaku dari generasi sebelumnya. Rata-rata penggunaan benih per hektar mencapai 30,12 kh/ha. Persediaan benih yang cukup banyak ini untuk mengantisipasi terjadinya permasalahan daya tumbuh benih, sehingga petani tidak sulit mendapatkan benihdalam melakukan proses penyulaman. Padi ladang yang digunakan petani di desa Nggela sebagian besar varietas ciherang dan beberapa petani menggunakan varietas lokal "Pare Ndale", informasi yang diperoleh dari lokasi penelitian bahwa varietas lokal ini lebih tahan terhadap serangan hama penyakit, namun petani lebih tertarik dengan varietas ciherang. Sehubungan dengan pemanfaatan varietas lokal, beberapa tahun terakhir PPL dan instansi terkait selalu memberi informasi agar masyarakat sedapat mungkin menggunakan varietas lokal Pare Ndale dalam kegiatan usahatani padi ladang, karena varietas lokal ini sangat sesuai dengan karakteristik lahan dan daya adaptasinya lebih baik.

Pupuk anorganik yang digunakan oleh petani di desa Nggela diantaranya pupuk urea SP 36 dan KCL. Penggunaan pupuk urea per hektar $52,10 \mathrm{~kg}$ per hektar, SP $3647,12 \mathrm{~kg}$ per hektar dan KCL 48,0 kg per hektar. Hasil wawancara dengan beberapa orang petani senior diperoleh informasi bahwa penggunaan ketiga jenis pupuk tersebut belum sesuai dengan rekomendasi yang diberikan untuk usahatani padi ladang khususnya di lahan kering, takaran yang dianjurkan masing-masing $250 \mathrm{~kg}$ urea/ha, $75 \mathrm{~kg} \mathrm{SP}$ 36/ha dan $50 \mathrm{~kg} \mathrm{KCL} / \mathrm{ha}$. Hasil penelitian juga menunjukkan bahwa petani jarang menggunakan pupuk kandang. Beberapa petani menggunakan limbah organik dari sisa-sisa tanaman (jerami, batang, dahan), kesimpulannya penggunaan pupuk organik pada usahatani padi ladang di desa Nggela masih relatif rendah. Secara teoritis, penggunaan pupuk organik dalam bentuk yang telah dikomposkan ataupun segar berperan penting dalam perbaikan sifat kimia, fisika, dan biologi tanah serta sebagai sumber nutrisi tanaman. Secara umum kandungan nutrisi haradalam pupuk organik tergolong rendah dan agak lambattersedia, sehingga diperlukan dalam jumlah cukup banyak. Namun, pupuk organik yang telah dikomposkan dapat menyediakan hara dalam waktu yang lebih cepat dibandingkan dalam bentuk segar, karena selama proses 
pengomposan telah terjadi proses dekomposisi yang dilakukan oleh beberapa macam mikroba.

Pestisida yang digunakan oleh petani di desa Nggela sangat bervariasi, hasil penelitian menunjukkan rata-rata penggunaan pestisida sebanyak $102 \mathrm{ml}$ per hektar, penggunaan pestisida yang sangat terbatas ini disebabkan karena keterbatasan uang untuk membeli pestisida. Di lokasi penelitian tidak ditemukan kios yang menjual saprodi, sehingga untuk membeli pestisida petani harus pergi ke kota dengan jarak $75 \mathrm{Km}$, dengan tambahan biaya transportasi ini, bagi petani biaya untuk usahatani padi ladang dirasakan sangat berat.Secara teoritis dijelaskan bahwa, penggunaan pestisida harus memperhatikan ambang batas, kelebihan penggunaan zat kimia ini akan berpengaruh pada ekosistem.

Penggunaan pestisida secara tidak bijaksana dapat menimbulkan berbagai dampak negatif baik bagi manusia maupun lingkungan. Hasil penelitian Ameriana et al.(2000) menunjukkan bahwa buah tomat dengan perlakuan pencucian saja hanya mampu mengurangi nilai inhibisi insektisida dari $61,17 \%$ menjadi $60,18 \%$ dan nilai inhibisi fungisida dari $70,64 \%$ menjadi $50,28 \%$. Perilaku petani dalam menggunakan pestisidakimiawi dapat disimpulkan bahwa : (a) semakin tinggipersepsi petani terhadap risiko maka semakin tinggikuantitas pestisida kimia yang digunakan, semakinrendah ketahanan suatu varietas terhadap serangan Opt,semakin tinggi kuantitas pestisida kimia yang digunakanoleh petani dan (c) semakin rendah pengetahuan petaniterhadap bahaya pestisida semakin tinggi pestisida yangdigunakan (Ameriana, 2008)

Tenaga kerja yang digunakan petani di desa Nggela sebagian besar adalah tenaga kerja keluarga. Penggunaan tenaga kerja luar keluarga hanya untuk pekerjaan pengolahan tanah, penanaman dan panen. Pengolahan tanah sudah menggunakan teknologi dalam hal ini hand traktor, sewa hand traktor untuk pengolahan lahan selama 2 minggu sebesar Rp 300.000. Hand traktor milik salah satu masyarakat di desa Nggela, terkadang petani harus menyewa hand traktor dari desa tetangga, jika hand traktor tersebut rusak. Tenaga kerja luar keluarga yang bekerja untuk kegiatan penanaman dan panen tidak dibayar/ tidak diberi upah, masyarakat masih terbiasa dengan kerja gotong royong, hari ini bekerja pada lahan keluarga yang lain hari berikutnya bekerja pada lahannya sendiri. Minimnya biaya tenaga kerja ini sangat membantu dalam menekan biaya produksi. Secara umum tenaga kerja usia produktif di desa Nggela cukup tersedia, namun tidak semua tenaga kerja tersebut berminat untuk bekerja disektor pertanin, sehingga rata-rata usia petani padi ladang di desa Nggela berada di atas 45 tahun. Kurang tertariknya generasi muda bekerja disektor pertanian ini menyebabkan jumlah petani padi ladang di desa Nggela hanya mencapai 53 orang petani. Menurut Saptana et al., (2010) penggunaantenaga kerja yang intensif terkait juga dengan usaha menanggulangi risiko secara interaktif 
dengan mengelola usahatani secara sungguh-sungguh. Artinya penambahan penggunaan tenaga kerja akan bersifat mengurangi risiko kegagalan usahatani.

\section{Risiko Produksi}

Analisis risiko produksi menggunakan koefisienvariasi (CV) kemudian dilakukan perbandingan risikoproduksi antara produksi padi ladang pada musim hujan danproduksi padi ladang pada musim kemarau.
Perbandingan dengan memperhatikan musim tanam ini memiliki keterkaitan erat dengan resiko yang harus diterima petani. Nilai koefisien variasi produksi yang kecil menunjukkan variabilitas nilai rata-rata produksi yang rendah, hal ini menggambarkan risiko produksi yang dihadapi untuk mendapatkan hasil produksi tersebut kecil, demikian sebaliknya. Perbandingan risiko produksi antara usahatani padi ladang antar musim pada Tabel I.

Tabel I.Produktivitas dan Resiko Usaha Tani Padi Ladang Berdasarkan Musi

\section{Uraian Produktivitas Usahatani Padi Ladang (Kwintal/Ha)}

Musim Tanam

\begin{tabular}{ccc} 
& Musim Kemarau & Musin Hujan \\
\hline Produktivitas & 10.01 & 20.00 \\
Standar deviasi & 782.321 & 610.211 \\
Koefisien variasi & 0.121 & 0.052 \\
CV $(\%)$ & 0.078 & 0.030 \\
\hline
\end{tabular}

Data pada Tabel 1 memberi gambaran tentang resiko produksi usahatani padi ladang pada musim hujan dan kemarau, dimana pada musim hujan lebih rendah dari pada musim kemarau. Fakta di lokasi penelitian ini disebabkan karena usahatani yang dilakukan merupakan usahatani padi ladang, ketergantungan dengan air hujan sangat tinggi untuk pertumbuhan dan produksi tanaman, sedangkan pada musim kemarau masyarakat kesulitan mendapatkan air, hanya pada beberapa petani yang melakukan kegiatan usahatani dimana kebun ladang letaknya dekat dengan sungai, pada musim kemarau debit air sungai sangat kecil. Untuk menjaga produktivitas usahatani padi ladang pada musim hujan sebagian besar masyarakat tani dilatih oleh PPL untuk mengetahui prevalensi serangan hama/penyakit, memetakan varietas spesifik, dan menerapkan teknik budi daya spesifik, misalnya rekomendasi pemupukan, jarak tanam, pengairan, dan pengelolaan hama/penyakit tanaman. Hal ini disadari karena pada musim hujan tingkat serangan penyakit lebih tinggi dibandingkan dengan musim kemarau, selain itu pada musim hujan intensitas radiasi matahari juga lebih rendah dibandingkan musim kemarau yang tentunya kan berpengaruh terhadap proses fotosintesis. Hasil penelitian ini berbeda dengan penelitian yang dilakukan oleh Ghani (2013)dan dan Suharyanto, et.al (2015) bahwa curah hujan termasuk faktor yang meningkatkan risiko. 


\section{Faktor-Faktor yang Mempengaruhi Resiko Produksi}

Sebelum dilakukan analisis pengaruh faktor-faktor produksi terhadap produksi padi ladang, maka didahului dengan uji asumsi klasik. Hasil uji penyimpangan asumsi klasik memberi suatu gambaran bahwa data terdistribusi normal, gejala multikolonieritas yang terjadi tidak serius, dan tidak tejadi gejala heterokedastisitas
Pengaruh faktor-faktor input produksi terhadap produksi dan resiko produksi dianalisis menggunakan fungsi produksi CobbDouglass, hasil analisis menunjukan limavariabel berpengaruh signifikan dan satu variabel yang tidak berpengaruh pada produksi dan resiko produksi padi ladang.Hasil penelitian pada Tabel 2 dan Tabel 3.

Tabel 2 Faktor-Faktor Yang Mempengaruhi Produksi Padi Ladang.

\begin{tabular}{lcccc}
\hline Variabel & Koefisien & Standar Error & T-Hitung & Probabilitas \\
\hline Konstanta & $7.241^{* * *)}$ & 0.421 & 29.300 & 0.000 \\
Lahan & $2.231^{* * *)}$ & 0.022 & 10.241 & 0.000 \\
Benih & $0.110^{* * *}$ & 0.131 & 9.231 & 0.000 \\
Pupuk & $0.102^{* *}$ & 0.222 & 1.872 & 0.062 \\
Pestisida & $0.021^{* *)}$ & 0.143 & 2.190 & 0.009 \\
TK & 0.117 & 0.310 & 0.124 & 0.123 \\
Dummy Musim & $\left.0.043^{* * *}\right)$ & 0.200 & 4.214 & 0.009 \\
Tanam & & & & \\
R-Squared & 0.832 & & & \\
Adjusted R-Squared & 0.841 & & & \\
F-Statistik & 151.201 & & & \\
\hline
\end{tabular}

Nilai koefisien determinasi $\left(\mathrm{R}^{2}\right)$ pada Tabel 1 sebesar 0.832 , nilai ini mengandung arti bahwa 83,2 persen variasi produksi usahatani padi ladang di desa Nggela dapat dijelaskan oleh semua variabel independen yang ada pada model, atau $83.2 \%$ variabel independen (lahan, benih, pupuk, pestisida, tenaga kerja dan dummy musim tanam) berpengaruh terhadap variabel dependen (produksi), sisanya $16.8 \%$ dipengaruhi oleh variabel lain diluar model. Nilai $F$ hitung pada Tabel 1 sebesar 151.201, nilai ini menunjukkan bahwa variabel independen secara bersama-sama berpengaruh signifikan terhadap variabel produksi padi ladang. Hasil uji t menunjukkan variabel bebas yang berpengaruh nyata dan bertanda positif terhadap variabel bebas (produksi padi ladang) adalah lahan, benih, pupuk dan pestisida, ini berarti jika jika penggunaan input lahan, benih, pupuk dan pestisida bertambah, maka produksi padi ladang meningkat, sedangkan variabel tenaga kerja tidak berpengaruh nyata, hal ini disebabkan karena masyarakat Nggela 
masih terbiasa dengan pola kerja gotong royong, sehingga besar atau kecilnya tenaga kerja yang ikut bekerja tidak berpengaruh terhadap biaya tenaga kerja. Variabel dummy musim tanam menunjukkan pengaruh yang signifikan, informasi ini menjadi petunjuk bagi masyarakat tani dalam mengelola usahatani dengan memperhatikan musim tanam yang tepat.

Hasil analisis pengaruh variabel independen lahan, benih, pupuk dan pestisida terhadap resiko produksi pada Tabel 3. Hasil analisis tersebut menunjukkan, nilai $\mathrm{R}^{2}$ yang diperoleh sebesar 41.2 persen, nilai $\mathrm{R}^{2}$ relatif kecil, hasil analisis dengan nilai yang kecil ini sama dengan beberapa penelitian salah satu diantaranya oleh Suharyanto, et.al (2015). Nilai $\mathrm{R}^{2}$ sebesar 41.2 persen mengandung makna 41,2 \% variabel independen lahan, benih, pupuk dan pestisida bersama-sama berpengaruh terhadap variabel dependen resiko produksi padi ladang dan sisanya sebesar 58.8 persen dipengaruhi oleh variabel lain diluar model diantaranya cuaca, dan hama penyakit. Resiko produksi yang disebabkan oleh cuaca dan hama penyakit masih sulit dikendalikan oleh petani, khususnya petani yang memiliki keterbatasan pengetahuan dan keterampilan.

Petani di desa Nggela sebagain besar merupakan petani subsisten, hasil produksi padi ladang hanya digunakan untuk memenuhi kebutuhan hidup sehari-hari, sehingga upaya untuk menambah pengetahuan dan keterampilan serta adopsi teknologi tepat guna melalui kursus atau pelatihan yang dibiayai sendiri untuk mengendalikan resiko usaha tani masih sangat sulit dilakukan. Pilihan memungkinkan hanya melalui program pemerintah dalam meningkatkan sumber daya petani di desa atau mengoptimalkan peran PPL.

Hasil analisis nilai $\mathrm{F}$ hitung sebesar 4.291, nilai ini mengandung arti bahwa variabel-variabel independen yang ada dimodel berpengaruh nyata secara simultas terhadap variabel resiko produksi. Hasil analisis uji $\mathrm{t}$ menunjukkan bahwa tidak semua variabel independen berpengaruh nyata pada variabel dependen. Variabel yang tidak berpengaruh yaitu variabel tenaga kerja. Data di lapangan menunjukkan bahwapengerjaan lahan di desa Nggela masih terbiasa dengan pola kerjasama, sehingga banyak atau sedikit tenaga kerja yang digunakan, atau banyak atau sedikit biaya tenaga kerja yang dikeluarkan tidak berpengaruh terhadap resiko produksi. Pada variabel lahan, benih, pupuk, dan pestisida menunjukkan pengaruh yang signifikan dan bertanda negatif, ini berarti setiap tambahan luas lahan, benih, pupuk dan pestisida akan menurunkan resiko produksi padi ladang.

Lahan pertanian di desa Nggela masih cukup luas, hasil penelitian menunjukkan masih cukup banyak lahan tidur, sehingga perluasan lahan untuk usaha tani padi ladang masih memungkinkan, dengan dukungan tenaga kerja dan faktor-faktor produksi lainnya. Untuk faktor produksi pupuk menunjukkan penambahan penggunaan pupuk dapat menurunkan resiko produksi, namun fakta dilapangan menunjukkan bahwa petani di desa Nggela dalam penggunaan pupuk masih relatif rendah, baik untuk pupuk anorganik maupun pupuk organik, hal ini disebabkan karena keterbatasan pengetahuan yang 
dimiliki serta daya beli petani yang masih sangat rendah, untuk itu petani diharapkan dalam penggunaan pupuk organik dapat memanfaatkan sumber bahan komposantara lain berasal dari limbah organik seperti sisa-sisatanaman (jerami, batang, dahan), kotoran ternak (sapi, kambing, ayam), sumber bahan kompos ini relatif lebih murah dan mudah didapat di desa. Manfaat dari penggunaan pupuk organik bagi petani adalah meningkatnya produktivitas dari lahan pertanian, karena dengan meningkatnya kadar kandungan bahan organik dan unsur hara yang ada dalam tanah, maka dengan sendirinya akan memperbaiki sifat, kimia dan biologi tanah atau lahan pertanian.

Tabel 3. Faktor-Faktor Yang Mempengaruhi Resiko Produksi Padi Ladang.

\begin{tabular}{lcccc}
\hline Variabel & Koefisien & Standar Error & T-Hitung & Probabilitas \\
\hline Konstanta & $6.141^{* * *)}$ & 0.301 & 13.212 & 0.000 \\
Lahan & $\left.-3.321^{* * *}\right)$ & 0.122 & 7.214 & 0.000 \\
Benih & $\left.-0.200^{* * *}\right)$ & 0.221 & 6.231 & 0.000 \\
Pupuk & $-0.203^{* *}$ & 0.101 & 1.021 & 0.120 \\
Pestisida & $\left.-0.101^{* *}\right)$ & 0.213 & 2.281 & 0.010 \\
TK & 0.127 & 0.210 & 0.031 & 0.211 \\
Dummy Musim & $0.033^{* * *}$ & 0.110 & 5.441 & 0.005 \\
Tanam & & & & \\
R-Squared & 0.412 & & & \\
Adjusted R-Squared & 0.456 & & & \\
F-Statistik & 4.291 & & & \\
\hline
\end{tabular}

Faktor produksi pestisida, hasil analisis menunjukkan penambahan penggunaan pestisida mampu menurunkan resiko produksi. Fakta dilapangan menunjukkan bahwa penggunaan pestisida masih relatif sangat rendah ditingkat petani, hasil wawancara dengan beberapa orang petani memberi gambaran bahwa, jika petani membutuhkan pestisida maka petani harus ke kota membeli dengan biaya yang relatif mahal karena harus ditambah biaya transportasi.Sebagain besar petani masih menggunakan pestisida kimiawi, penggunaan pestisida nabatai masih sangat terbatas jumlahnya. Dalam penggunaan pestisida harus memperhatikan ambang batas, agar tidak memberi dampak positif pada tanah maupun hasil produksi. Hasil penelitian Ameriana (2008), tentang perilaku petani dalam menggunakan pestisidakimiawi dapat disimpulkan bahwa : (a) semakin tinggipersepsi petani terhadap risiko maka semakin tinggikuantitas pestisida kimia yang digunakan, (b) semakinrendah ketahanan suatu varietas terhadap serangan OPT,semakin tinggi kuantitas pestisida kimia yang digunakanoleh petani dan (c) semakin rendah pengetahuan 
petaniterhadap bahaya pestisida semakin tinggi pestisida yangdigunakan

Hama yang sering menyerang tanaman padi ladang di desa Nggela adalah walang sangit, tikus sawah, dan burung. Penyakit yang sering menyerang tanaman padi adalah penyakit yang umumnya disebabkan oleh jamur, bakteri, dan virus. Hasil wawancara dengan PPL diperoleh informasi bahwa, pengendalian hama dan penyakit yang dilakukan selama ini yaitu dengan menerapkan pengendalian hama dan penyakit secara terpadu.Pengendalian ini dilakukan dengan penanaman serempak, melakukan pergiliran tanaman,penyemprotan dengan pestisida yang efektif dan bijaksana, dan penggunaan varietas unggul yang tahan terhadap hama dan penyakit. Hasil wawancara dengan beberapa petani diperoleh informasi, pelaksanaan pengendalian hama dan penyakit secara terpadu belum dilakukan secara efektif, hal ini disebabkan karena setiap petani memiliki pengetahuan dan keterampilan yang berbeda.

Untuk faktor produksi benih hasil analisis menunjukkan bertambahnya penggunaan benih mampu menurunkan resiko produksi, analisis ini sesuai dengan fakta di lapangan bahwa usahatani padi pada lahan kering kemungkinan gagal tanam cukup besar, sehingga penggunaan benih yang cukup membantu menurunkan resiko produksi, disamping itu lahan pertanian yang masih luas memungkinkan petani untuk melakukan ekstensifikasi usaha dengan memanfaatkan ketersediaan benih yang ada.

\section{SIMPULAN}

Hasil penelitian menunjukkan resiko produksi usahatani padi ladang pada musim hujan lebih rendah jika dibandingkan pada musim kemarau, hal ini dipengaruhi oleh kebutuhan air dalam menjalankan kegiatan usahatani. Pada musim kemarau lahan relatif kering dan pecah sehingga petani kesulitan dalam menjalankan kegiatan usahatani. Faktorfaktor yang mempengaruh resiko produksi padi ladang meliputi, lahan, benih, pupuk dan pestisida, pada faktor produksi tenaga kerja tidak berpangaruh nyata, hal ini dipengaruhi oleh pola kerjasama yang sudah membudaya pada masyarakat desa Nggela.

\section{DAFTAR PUSTAKA}

Ameriana, M. 2008. Perilaku Petani Sayuran dalamMenggunakan Pestisida Kimia. Jurnal Hortikultura 18(1) : 95-106.

Ameriana. M., R. Sinung-Basuki., E. Suryaningsih dan W. Adiyoga. 2000. Kepedulian Konsumen terhadap Sayuran Bebas Residu Pestisida. J. Hort .9(4):377-377.

Arifin. 2013. Resiko Produksi dan Pendapatan Kepemilikan Lahan Daerah Sentra Produksi Padi di Kabupaten Pinrang. Jurnal Vegeta 7 (1) : 1-14.

Ghani, M.A. 2013. Dampak Perubahan

Iklim TerhadapHasil dan Risiko Produksi Padi di Indonesia. ThesisProgram Studi Ilmu

Ekonomi. Fakultas Ekonomi.Universitas Indonesia. Jakarta. (Tidak dipublikasikan).

Ihsanudin. 2010. Resiko Usahatani Tembakau di Kabupaten Magelang. Jurnal Embryo. 7 (1) : 21-28.

Kadarsan, H.W. 1995. Keuangan Pertanian dan Pembiayaan Perusahaan 
Agribisnis. Cetakan Kedua.PT.

Gramedia Pustaka Utama. Jakarta.

Lamusa A. 2010. Resiko Usahatani Padi

Sawah Rumah Tangga Di Daerah Impenso Provinsi Sulawesi Tengah.

Jurnal Agroland. 17(3):226-232

Lanamana Willybrordus. 2016. Efisiensi

Usahatani Padi Ladang dan Usaha

Konservasi Pada Tanah Hak Ulayat

di Desa Mausambi Kecamatan

Maukaro Kabupaten Ende. Laporan

Hasil Penelitian. Perpustakaan

Universitas Flores Ende.

Roumasset, J.A. Baussard, J.A. and Singh

I. 2000. Risk. Uncertainty And

Agriculture Development Searca and ADC

Saptana, A. Daryanto., H.K. Daryanto dan

Kuntjoro. 2010.Strategi Manajemen

Risiko Petani Cabai Merah

PadaLahan Sawah Dataran Rendah

di Jawa Tengah. JurnalManajemen

dan Agribisnis 7 (2) : 115-131.

Semaoen. I. 2000. Ekonomi Produksi

Pertanian Teori dan Aplikasi. Ikatan

Sarjana Ekonomi Indonesia Jakarta

Suryana A., S. Mardianto, K. Kariyasa

dan I.P. Wardhana.2009.

Kedudukan Padi Dalam

Perekonomian Indonesia dalam

Padi,Inovasi Teknologidan

Ketahanan Pangan.Buku1.Balai

Besar Penelitian Tanaman

Padi.Badan Penelitian dan

Pengembangan

Pertanian.Jakarta.Hal 7- 31.

Suharyanto, Rinaldy, Arya. 2015. Analisis

Resiko Produksi Usahatani Padi

Sawah di Bali. Journal of

Agribusiness and Rural

Developmnet Research. Universitas

Muhamadiyah Yogyakarta

Soedjana, T.D. 2007. Sistem Usahatani

Terintegrasi Tanaman Ternak
Sebagai Respons etani Terhadap

Faktor Risiko. Jurnal Litbang

Pertanian 26 (2) : 82-87. 